\title{
IMPLIKASI HERMENEUTIS MEMBACA INJIL-INJIL KANONIK SEBAGAI TULISAN BIOGRAFI YUNANI-ROMAWI
}

\author{
Herry Susanto \\ Sekolah Tinggi Alkitab Tiranus \\ Jl. Cihanjuang Km. 5,2, Cihanjuang, Parongpong, Bandung Barat, Jawa Barat \\ Email: herrysusanto@protonmail.com
}

\begin{abstract}
Herry Susanto, The Hermeneutical Implication of Reading the Canonical Gospels as Greco-Roman Biographical Writing. Historical method and narative criticism are the two approaches that have become important tools in exegetical work of canonical Gospels. Both have given important contribution, however the two approaches have inadequacies. The historical approach depends on external data, and narrative criticism tends to treat the Gospel texts as modern narratives. In the subsequent development of studies on the canonical Gospels, it has been found some significant similarities between the Gospels and Greco-Roman biographical writings. This writing observes three similarities, namely the format of content, focus of story and purpose. The content of Greco-Roman biography, mostly narrates the public work or ministry of the main character. The same thing is found on the Gospels. Likewise, the focus of story that orients to one main character and the purpose of authorship that has rhetorical and persuasive element. The similarities indicate that the canonical Gospels may be categorized as GrecoRoman biographical genre. Certainly, it has hermeneutical implication. The Gospels should be read in accordance with its genre.
\end{abstract}

Keywords: Canonical Gospels, Greco-Roman biography, hermeneutics, historical method, narative criticism.

\begin{abstract}
ABSTRAK: Herry Susanto, Implikasi Hermeneutis Membaca Injil-Injil Kanonik sebagai Tulisan Yunani-Romawi. Metode historis dan kritik naratif merupakan dua pendekatan yang telah menjadi alat penting dalam karya eksegesa Injil-Injil kanonik. Keduanya telah memberi kontribusi penting, namun dua pendekatan tersebut memiliki kelemahan. Pendekatan historis bergantung pada data eksternal, dan kritik naratif cenderung memperlakukan teks-teks Injil sebagai naratif modern. Dalam perkembangan selanjutnya studi terhadap Injil-Injil kanonik, didapati kesamaan-kesamaan yang signifikan antara kitabkitab Injil dengan tulisan biografi Yunani-Romawi. Tulisan ini melihat tiga kesamaan, yaitu format isi, fokus cerita dan tujuan. Isi biografi Yunani-Romawi, sebagian besar menceritakan karya atau pelayanan publik tokoh utama. Hal yang sama dijumpai pada kitab-kitab Injil. Demikian juga dengan fokus cerita yang berorientasi kepada satu tokoh utama dan tujuan penulisan yang memiliki unsur retoris dan persuasif. Kesamaan-kesamaan ini tentu mengindikasikan bahwa Injil-Injil kanonik dapat dikategorikan bergenre biografi Yunani-Romawi. Ini tentu memiliki implikasi hermeneutis. Kitab-kitab Injil harus dibaca sesuai dengan genrenya tersebut.
\end{abstract}

Kata Kunci: Injil-Injil kanonik, biografi Yunani-Romawi, hermeneutik, metode historis, kritik naratif.

\section{PENDAHULUAN}

Dalam studi terhadap Injil-Injil kanonik, pendekatan historis dan kritik naratif (narrative criticism) telah menjadi alat penting dalam proses eksegesa. Pendekatan historis, yang terefleksikan oleh metode-metode seperti kritik bentuk (form criticism), kritik redaksi (redaction criticism) dan kritik sosio-historis (socio-historis criticism), telah menolong penafsir merekonstruksi asal mula dan banyak unsur dari latar belakang teks. Dalam perkembangan selanjutnya, pendekatan kritik naratif bisa dianggap sebagai penyeimbang, karena mengajak pembaca masa kini untuk menghargai unsur-unsur literer yang membangun catatan-catatan Injil sebagai cerita. Bila pendekatan historis menggunakan banyak bahan-bahan eksternal, maka kritik naratif lebih cenderung menerapkan pembacaan mendalam (in-depth reading) dengan berfokus pada elemen-elemen internal teks. 
Kemudian, beberapa ahli biblika menemukan kesamaan signifikan antara kitab-kitab Injil dan tulisan biografi Yunani-Romawi (Greco-Roman biography). Ahli Perjanjian Baru seperti Richard Burridge, David E. Aune dan Craig Keener menemukan bahwa Injil kanonik lebih tepat dikategorikan sebagai tulisan biografi kuno, dalam hal ini adalah biografi Yunani-Romawi.

Artikel ini memperlihatkan bahwa membaca kitab-kitab Injil sebagai naratif-biografi kuno adalah cara yang tepat dalam memperlakukan Injil-Injil kanonik sesuai dengan genrenya. Dalam temuannya, artikel ini akan menyoroti, pertama, prinsip penggunaan pendekatan historis dalam menggali kitab Injil dan kelemahannya; yang akan menjadi sorotan adalah kritik bentuk, kritik redaksi dan metode sosiohistoris. Kedua, akan ditelusuri kelebihan dan kekurangan metode kritik naratif yang adalah penyeimbang pendekatan historis. Ketiga, akan dijelaskan kesamaan antara Injil kanonik dan biografi YunaniRomawi dan kelebihan-kelebihan dalam membaca teks-teks Injil sebagai tulisan biografi kuno. Terakhir, tulisan ini akan mencoba menjelaskan implikasi hermeneutis Injil sebagai tulisan biografi YunaniRomawi.

\section{METODE}

Artikel ini merupakan tulisan kualitatif yang bertujuan memperlihatkan pentingnya membaca InjilInjil kanonik sebagai tulisan biografi kuno. Maka artikel ini mencoba untuk mengelaborasi signifikansi dari pendekatan tersebut dalam kaitan dengan genre kitab Injil. Data-data diperoleh melalui observasi literatur. Karya-karya dari ahli Perjanjian Baru seperti Richard Burridge, David Aune dan Richard Resseguie menjadi perhatian penting dalam analisa artikel ini.

Secara spesifik, tulisan ini akan mendeskripsikan kaitan Injil-Injil kanonik dengan genre biografi Yunani-Romawi, serta implikasi hermeneutis dari keterkaitan tersebut. Akan terlihat komparasi antara pendekatan historis dan kritik naratif dengan membaca teks-teks Injil sebagai tulisan biografi kuno.
Dari komparasi ini akan didapati kelebihan-kelebihan membaca Injil-Injil kanonik sebagai biografi Yunani-Romawi. Dari sini kemudian dideskripsikan implikasi-implikasi yang muncul terkait dengan penggalian isi Injil-Injil kanonik.

\section{HASIL DAN PEMBAHASAN}

Hal yang perlu untuk dibahas adalah bagaimana pendekatan historis telah digunakan dalam studi terhadap Injil-Injil kanonik. Kemudian diteruskan tinjauan terhadap penerapan kritik naratif. Kedua penelusuran ini akan menunjukkan prinsip-prinsip yang digunakan. Ini akan menolong untuk melihat kekurangan yang ada pada pendekatan historis dan kritik naratif dalam membaca Injil-Injil.

Asumsi tulisan ini adalah kitab-kitab Injil memiliki kesamaan dengan tulisan biografi YunaniRomawi. Kesamaan tersebut menunjukkan bahwa Injil-Injil bisa dikategorikan sebagai tulisan bergenre biografi kuno. Tentu ini perlu pembuktian, maka akan ditinjau tiga kesamaan, yaitu format isi, fokus cerita dan tujuan. Lalu dilanjutkan dengan kelebihan apa yang bisa diperoleh dengan membaca Injil-Injil sebagai biografi Yunani-Romawi.

Keterkaitan dengan genre biografi kuno ini menentukan cara pendekatan terhadap Kitab-Kitab Injil. Bagian pembahasan ini akan ditutup dengan implikasi hermeneutis dari membaca Injil-Injil sebagai tulisan biografi Yunani-Romawi.

\section{Injil dan Analisa Historis}

Menganalisa dimensi historis adalah pendekatan yang sangat berpengaruh dalam studi terhadap kitab-kitab Injil. Ini terlihat pada pendekatan kritik bentuk dan kritik redaksi, yang memposisikan latar belakang sejarah menjadi substansial. Dalam kaca mata kritik bentuk, naratif Injil adalah koleksi tradisi-tradisi Yesus yang dikombinasikan tanpa ada proses redaksi (Travis, 1977). Sedikit berbeda, kritik redaksi berkeyakinan bahwa di balik kitab-kitab Injil ada keterlibatan penulis atau redaktur yang secara kreatif mengembangkan tulisan tersebut. Sekalipun keduanya berbeda dalam memandang asal mula dari 
teks Injil-Injil kanonik, namun terdapat kesamaan bahwa kritik bentuk dan kritik redaksi bergantung pada analisa historis. Kritik bentuk mengaitkan Kitab Injil dengan tradisi keagamaan gereja mula-mula, dan kritik redaksi berorientasi pada latar belakang para penulis kitab Injil dan komunitas yang menggunakan tulisan mereka. Pada umumnya, pendekatan terhadap Injil-Injil kanonik di abad ke-20 lebih dipengaruhi oleh para ahli biblika Jerman, misalnya Karl Ludwig Schmidt dan Rudolf Bultmann. Landasan keyakinan tentang natur dari teks adalah InjilInjil tidak dapat dikategorikan ke dalam salah satu genre literatur (Walton, 2015). Teks-teks Injil adalah kumpulan bermacam tradisi oral tentang kehidupan Yesus yang bertujuan untuk menopang tradisi penyembahan terhadap Yesus. Maka kunci dari tindakan eksegesa adalah merekonstruksi Sitz im Leben teks, guna menemukan laporan yang autentik dan bagaimana cerita tersebut ditransmisikan (kritik bentuk dan kritik redaksi) (Walton, 2015, p. 85).

Dalam perkembangan berikutnya, interes terhadap analisa historis menjadi lebih intens dan ekstensif dengan menerapkan metode dari displin ilmu sosial. Dengan pendekatan tersebut, analisa historis meluaskan fokusnya pada suasana ekonomi, politik dan kehidupan sosial di balik kitab-kitab Injil.

Dalam studi terhadap bagian-bagian tertentu dari kitab Injil, dimensi historis dan sosial menjadi sorotan utama. Sebagai contoh, investigasi terhadap Lukas 4:16-30 yang menjadi dasar banyak pemikiran teologi pembebasan, lebih banyak berkonsentrasi pada dimensi sosial dan historis. Contoh dari karyakarya tersebut dapat dilihat dalam tulisan oleh Prior (1995); Abogunrin (2003); Finkel (1994); Hill (1971); Kimball (1994); Poirier (2009); Ringe (1981); Siker (1992).

Dalam perkembangan studi terhadap InjilInjil kanonik, pendekatan historis telah berkontribusi banyak. Analisa historis telah menolong banyak pembaca Alkitab menelusuri asal-usul teks dan bentuknya sebelum dituangkan dalam bentuk tulisan. Penelusuran unsur historis teks, dalam batas tertentu, telah menolong pembaca masa kini untuk memper- kirakan bagaimana jemaat mula-mula menggunakan teks-teks kanonik dalam tradisi keagamaan Kristen perdana (kritik bentuk). Di samping itu, tinjauan terhadap unsur-unsur redaksional teks akan menolong penafsir memperkirakan elemen-elemen yang mempengaruhi pengolahan isi teks oleh penulis (kritik redaksi); elemen-elemen tersebut bisa saja terkait dengan situasi budaya, ekonomi dan politik pembaca dan penulis (analisa sosio-historis).

Namun, bukan berarti pendekatan tersebut tanpa kekurangan, khususnya terkait dengan kebergantungan pada rekonstruksi sejarah. Keempat Injil adalah tulisan anonim. Di samping itu, informasi yang bisa digunakan untuk merekonstruksi penulis, pembaca, waktu penulisan dan latar belakang teks sangat minim. Penjelasan Joel B. Green tentang anonimitas kitab Injil Lukas - bisa diterapkan terhadap Injil-Injil kanonik lainnya - menjelaskan bahwa pembaca masa kini tidak memiliki akses yang memadai untuk mengetahui penulis yang sebenarnya (Green, 1972, p. 21). Hal ini serupa dengan unsur-unsur historis lainnya seperti penerima, tanggal dan historisitas peristiwa. Sebagaimana dijelaskan oleh Burridge bahwa kitab-kitab Injil tidak mengindikasikan adanya data-data yang memadai bagi pembaca untuk mengetahui dengan pasti semua unsur-unsur yang mendorong penulis untuk menuliskan karyanya dan ditujukan kepada siapa karya tersebut (Burridge, 2005, p. 108). Dengan demikian apa yang dimiliki dari kitab-kitab Injil tidak cukup untuk membangun sebuah rekonstruksi sejarah yang komprehensif. Fakta ini memperlihatkan bahwa analisa historis memiliki kelemahan bila digunakan sebagai metode utama dalam mempelajari naratif Injil. Oleh sebab itu analisa historis tidak bisa menjadi satu-satunya alat yang menolong penafsir untuk menggali isi teks.

Di samping itu, analisa historis juga mengabaikan natur dari tulisan Injil kanonik sebagai naratif kuno. Penting untuk dipahami bahwa tulisan Injil kanonik tidak didesain sebagai tulisan sejarah, sekalipun memberikan laporan tentang hidup dan pelayanan Yesus Kristus. Dalam kaca mata historiografi kuno, laporan sejarah adalah alat retorika (lih. 
Marshall, 1970; Ommeren, 1991; Uytanlet, 2014). Dalam konteks ini, detail-detail yang melatarbelakangi cerita belum tentu menjadi elemen penting dalam memahami teks. Dengan asumsi bahwa unsur retorik sangat penting dalam historiografi kuno, maka pertanyaan mendasar yang perlu dijawab dalam proses eksegesa adalah mengapa penulis menuliskan naratifnya; atau apa tujuan dari teks.

\section{Injil dan Kritik Naratif}

Pada tahun 1980an, dalam dunia studi biblika, kritik naratif hadir sebagai penyeimbang bagi metode yang lebih fokus pada analisa historis. Bila pendekatan seperti kritik bentuk, kritik redaksi dan kritik sosial-historis berupaya melakukan rekonstruksi sejarah, maka kritik naratif memberikan perhatian pada elemen-elemen internal teks. Karena memandang naratif Alkitab sebagai cerita, maka kritik naratif berfokus pada unsur-unsur literer teks. Kritik naratif sendiri merupakan kelanjutan dari kritik literatur yang terlebih dahulu diterapkan dalam studi teks (Banks, 1992; Bartchy, 1998; McKnight, 1992).

Dengan natur tersebut, kritik naratif tidak membangun gagasannya dengan mengandalkan data-data eksternal, melainkan membangunnya berdasarkan informasi internal cerita. Salah satu karya yang memberikan kontribusi penting bagi studi terhadap kitab-kitab Injil dengan menggunakan pendekatan kritik naratif adalah tulisan Rhoad dan Michie, Mark as Story (1982). Buku ini kemudian diikuti oleh ahli biblika lainnya seperti Kingsbury (1988), Culpepper (1983) dan Tannehill (1986). Kesamaan dari kesemua tafsir tersebut adalah mereka tidak bergantung pada investigasi historis untuk mencapai tujuan dari tafsir mereka, melainkan mengandalkan elemen-elemen literatur yang membangun cerita.

Secara praktis, kritik naratif menerapkan strategi modern dalam membaca naratif-naratif Alkitab (Resseguie, 2015, p. 19; lihat juga Bartchy, 1998, p. 787). Pengadopsian strategi tersebut berdasarkan keyakinan bahwa semua cerita memiliki kesamaan karakteristik meskipun ditulis dalam konteks waktu yang berbeda. Berdasarkan strategi tersebut ada dua dasar dalam penerapan kritik naratif, yaitu: (1) teks dipahami sebagai satu kesatuan; (2) tidak berkonsentrasi pada historisitas cerita, melainkan artistik literaturnya.

Maka, ada dua kelebihan dari kritik naratif. Pertama, pendekatan ini menolak ide fragmentasi naratif Alkitab (Resseguie, 2015, p. 38). Menurut Tannehill (1986, p. xiii), tema utama dari cerita mengikat seluruh adegan-adegan yang berbeda. Dalam kritik naratif, kesatuan teks adalah keniscayaan. David E. Aune (2003, p. 315) menjelaskan bahwa kesatuan teks merupakan core value bagi pendekatan kritik naratif. Dengan melihat teks cerita sebagai satu kesatuan, pembaca akan tetap mengaitkan bagianbagian cerita dengan tema besar yang mengikat teks.

Kedua, kelebihan yang lain adalah kritik naratif menolong pembaca melihat Injil kanonik sebagai cerita. Memahami teks Alkitab sebagai cerita sangat menolong para pembaca masa kini mendalami teks dalam konteks mereka. Ketika menelusuri isi kitab Injil dengan berorientasi pada naturnya sebagai cerita, maka teks tidak hanya dilihat sebagai tulisan historis, melainkan tulisan yang memiliki makna bagi umat di segala generasi.

Dalam konteks Perjanjian Baru, Tarmedi (2013, pp. 339-340) menjelaskan sebagai berikut:

Dalam Perjanjian Baru, distansi sejarah menjadi ranah pemberian makna atas pengalaman, yakni pengalaman iman akan Allah melalui pergaulan dengan Yesus, Sang Sabda yang menjadi daging. Para murid dan jemaat Kristen perdana, misalnya, mereka kemudian dibawa pada memori akan ramalan para nabi ketika melihat apa yang terjadi dengan Yesus Kristus. Kelahiran Yesus dari Perawan Maria mengingatkan mereka akan apa yang diramalkan nabi Yesaya, demikian juga dengan kisah sengsara Yesus yang mengingatkan mereka tentang hamba Tuhan yang menderita (Yes. 52:13-53:12). Ketika Para Rasul berkumpul, pasca kematian dan kebangkitan Yesus, kita bisa mengandaikan bahwa mereka bukan hanya berkumpul, berdoa, dan memecahkan roti (lih. Kis. 1:12-14; 2:41-47) melainkan juga berdiskusi dan berkisah tentang Yesus dan Kitab Suci. Mereka berkisah satu sama lain, mengenang sabda dan tindakan Yesus ... mereka juga serentak membangun makna 
baru untuk masa depan. Hal itu berarti mengoleksi makna dan menempatkannya dalam karya keselamatan Allah yang baru, Perjanjian Baru.

Penjelasan di atas memperlihatkan bahwa dalam konteks dunia naratif, kisah asal akan dipahami secara progresif. Isi cerita akan dimaknai secara baru dalam konteks yang berbeda. Secara hermeneutis, teks Alkitab akan dibawa ke dalam situasi hidup konkret warga gereja masa kini agar mereka memperoleh arah hidup (Tarmedi, 2013, p. 341).

Inilah yang menjadi perhatian praktik kritik naratif, mencari makna kisah dalam konteks kekinian. Kemunculan makna tidak hanya terjadi dalam origin event, melainkan terus muncul di dalam generasi dan konteks waktu-geografis yang berbeda. Makna akan lahir sesuai keadaan dan kebutuhan pembaca. Praktik seperti ini menolong dalam menjembatani distansi antara teks dan pembaca, sehingga Kitab Suci memiliki makna bagi umat di segala abad.

Namun bukan berarti kritik naratif tanpa kelemahan. Pendekatan yang mengadopsi metode modern dalam menelaah naratif ini, telah mengabaikan natur Injil kanonik sebagai tulisan kuno. Powell mengatakan, “... narrative critics may be charged with anachronistically applying modern concepts to ancient literature ..." (1995, pp. 239-255). Kritik naratif tentu memiliki nilai manfaat, namun metode ini cenderung mengabaikan genre Injil kanonik sebagai tulisan kuno.

Genre merupakan elemen prinsipil dalam menganalisa sebuah tulisan. Genre menentukan bagaimana sebuah tulisan mengomunikasikan ide, sehingga genrelah akan mengarahkan pembaca dalam menentukan cara memperlakukan sebuah tulisan. Dalam kaitannya dengan konteks literer sebuah tulisan, genre tidak bersifat universal karena sangat dipengaruhi oleh konteks waktu, tempat dan budaya (Talbert, 1988, p. 54). Sehingga benar yang dikatakan oleh Larry Hurtado: "In seeking to determine a writing genre, therefore, we must work with the genres and literary conventions relevant to the era of the writing" (1992, p. 277). Dengan demikian, memahami sebuah isi tulisan, teks harus dibaca dan dipahami sesuai dengan karakteristik literatur dalam konteks waktu teks itu sendiri. Sekalipun naratif Injil memiliki kesamaan dengan naratif modern secara karakteristik, namun Injil-Injil kanonik tetap merupakan tulisan yang muncul dalam konteks era Yunani-Romawi abad pertama, sehingga elemenelemen budaya literatur pada masa itu melekat dalam naratif Injil.

\section{Kitab Injil Sebagai Biografi Kuno}

Berdasarkan tinjauan di atas masih ada kekurangan yang harus diatasi terkait dengan penggunaan pendekatan historis dan kritik naratif dalam membaca Injil-Injil kanonik. Kekurangan dari pendekatan historis yang terlalu bergantung pada datadata eksternal terkait dengan upaya melakukan rekonstruksi sejarah telah coba diatasi dengan kritik naratif yang cenderung berfokus pada unsur-unsur internal teks. Namun kritik naratif belum menghubungkan kitab Injil dengan genre tulisan yang relevan, sehingga tidak melihat teks sebagai tulisan kuno.

Pada bagian ini akan diulas hubungan antara Injil kanonik dengan biografi Yunani-Romawi. Sebelum itu penting untuk melihat perbedaan mendasar antara biografi kuno dalam konteks dunia Helenis dengan biografi modern. Tujuannya adalah agar kitab Injil tidak dibaca dari kaca mata kultur literatur modern. Sebagai literatur yang menceritakan kehidupan seorang tokoh, biografi modern dan biografi kuno memiliki kesamaan. Namun terkait cara memperlakukan tokoh tersebut, keduanya memiliki perbedaan yang signifikan. Burridge lebih memilih istilah bios untuk dikenakan kepada biografi YunaniRomawi (Burridge, 2004, p. 60). Pemakaian istilah ini bertujuan untuk memberi perbedaan yang jelas antara kedua jenis tulisan biografi.

Tulisan biografi yang dipahami di era modern telah mengalami beberapa perubahan, khususnya terkait dengan fokus dari cerita. Sebagaimana yang disoroti oleh Burridge:

... our modern understanding of biography really comes to birth in the late nineteenth century after Freud. This is where we become 
interested in the nature of the individual human personality; after Marx, we want to understand people in their political setting; after Weber and Durkheim, people are placed in their sociological setting. Thus, our understanding of modern biography grows and develops throughout the nineteenth and twentieth centuries (Burridge, 2013, p. 14).

Dari pernyataan di atas, jelas bahwa ada perubahanperubahan dalam mendekati tulisan biografi. Maka bisa dipastikan bahwa ada perbedaan antara biografi kuno dan biografi modern. Perbedaan yang paling mendasar adalah biografi modern bertujuan untuk melaporkan perkembangan personaliti tokoh utama, sedang biografi Yunani-Romawi menggunakan tokoh utama sebagai media untuk menampilkan norma-norma atau nilai-nilai tertentu (Aune, 1987, pp. 27-28). Jadi, berbeda dengan biografi modern yang bertujuan melaporkan perjalanan hidup tokoh utamanya, biografi Yunani-Romawi merupakan tulisan retorika yang mencoba meyakinkan pembacanya akan norma atau paham tertentu dengan menjadikan bagian tertentu dari perjalanan hidup tokoh utama sebagai alat retorik-umumnya adalah karya publiknya.

Sebelumnya Injil-injil dipandang sebagai tulisan dengan genre yang unik. Kemudian oleh temuan-temuan para ahli Perjanjian Baru seperti Talbert dan Burridge, Kitab Injil lebih dipandang sebagai tulisan biografi kuno. Sebagaimana dijelaskan oleh Michael R. Licona bahwa pada mulanya keempat Injil dikelompokkan sebagai tulisan sui generis. Kemudian Talbert melalui karyanya What is a Gospel (1977) mengusulkan bahwa Injil seharusnya dikategorikan sebagai tulisan biografi. Ini kemudian disusul oleh Burridge dalam karyanya What Are the Gospels? (Licona, 2017, p. 3).

Untuk melihat keterkaitan antara Injil-Injil kanonik dengan genre biografi Yunani-Romawi, tentu perlu menemukan kesamaan-kesamaan signifikan. Tulisan ini fokus pada tiga kesamaan, yaitu kesamaan dalam format isi, fokus cerita dan tujuan. Pertama, terkait dengan format isi, biografi Yunani-Romawi menggunakan sebagian besar naratif untuk menceritakan karya publik tokoh utama. Penelitian oleh Burridge (2004, pp. 132-133), sangat menolong dalam melihat alokasi adegan-adegan dalam beberapa biografi kuno. Sebagai contoh, dalam tulisan biografi kuno Agesilaus karya Xenophon, terlihat persentase struktur sebagai berikut: (1) pendahuluan dan kehidupan awal tokoh (4\%); (2) serangan ke Persia (37,4\%); serangan-serangan lainnya dan aktivitas tokoh (12,7\%); kesalehan tokoh utama $(35,2 \%)$; dan kesimpulan $(10,7 \%)$. Jelas bahwa karya publik tokoh utama menjadi sorotan dalam tulisan biografi kuno. Contoh yang lain yang disajikan oleh Burridge, yang menunjukkan hasil yang sama bahwa penulis biografi lebih tertarik pada karya publik individu yang diceritakan, adalah karya berjudul $E v$ agoras oleh Isocrates dan Atticus oleh Nepos.

Terkait dengan Injil-Injil kanonik, kembali mengacu pada penelitian Burridge (2004, pp. 191192), maka didapati karakteristik yang sama. InjilInjil kanonik memperlihatkan bahwa pelayanan publik Yesus menjadi sorotan penting. Sebagai contoh, untuk Injil Lukas, Burridge melaporkan sebagai berikut: (1) pendahuluan $0,4 \%$; (2) kisah masa kecil 11,1\%; (3) persiapan dan permulaan pelayanan 4,4\%; (4) pelayanan di Galilea 23,9\%; (5) perjalanan ke Yerusalem 35,3\%; (6) pelayanan di Yerusalem 9,3\%; dan (7) perjamuan terakhir, kematian dan kebangkitan 15,6\%. Berdasarkan persentase ini, dalam melaporkan kehidupan Yesus, penulis Injil menggunakan porsi naratifnya lebih banyak untuk menceritakan aktivitas di Galilea, perjalanan dan pelayanan di Yerusalem. Maka pelayanan publik Yesus adalah unsur penting dalam Injil kanonik.

Dengan demikian bisa terlihat bahwa dari segi karakteristik isi, Injil kanonik dan biografi Yunani-Romawi memiliki kesamaan. Keduanya memberikan jumlah pelaporan yang lebih besar pada karya atau aktivitas publik tokoh utama.

Kedua, tulisan biografi fokus pada satu tokoh utama. Berkenaan dengan sorotan biografi kuno, Licona mengatakan, bahwa yang menjadi fokus dari tulisan biografi kuno adalah satu tokoh utama (2017, p. 3). Aune menyatakan hal yang sama bahwa satu 
tokoh utama menjadi perhatian dari asal mulanya sampai dengan kematiannya (1987, p. 33). Melalui tokoh utama ini, penulis biografi akan menampilkan ideologi yang ingin disampaikan (Kloppenborg, 2011, p. 342). Oleh sebab itu tokoh-tokoh yang diangkat ke dalam cerita adalah orang-orang yang terhormat atau memiliki peran penting di dalam masyarakat, misalnya tokoh pembangunan atau filsuf (Aune, 1987, p. 33). Berkaitan dengan hal ini, Burridge menjelaskan lebih spesifik dengan menggunakan contoh. Salah satu contohnya adalah Agesilaus, karya Xenophon. Agesilaus yang menjadi tokoh utama dalam biografi tersebut, dalam 370 kalimat atau frasa-frasa penting, ditemukan kemunculan namanya sebanyak 69 kali, yang bila dibandingkan dengan tokoh yang lain, ini sebesar 18,7\%. Kemunculan kedua terbesar adalah orang-orang Yunani yang hanya 10\%; tentu tokoh-tokoh yang lain di bawah persentase ini. Di samping itu, jumlah kemunculan nama Agesilaus dalam bentuk nominatif, juga yang terbesar dibanding tokoh-tokoh yang lain, yaitu 9,5\%. Tepat di bawah Agesilaus adalah orangorang Persia yang hanya sebesar 1,6\% (Burridge, 2004, p. 311). Maka dapat dilihat tulisan biografi kuno menyoroti satu karakter utama.

Berkenaan dengan Injil-Injil, Burridge menunjukkan bahwa dalam Injil-Injil Sinoptik, Yesus menjadi subjek dari 24,4\% kata kerja dalam Injil Matius; untuk Markus dan Lukas 17,2 \% dan 17,9\% (2004, p. 190). Dengan persentase yang demikian Yesus lebih dominan dari tokoh-tokoh lain. Injil Yohanes menunjukkan karakteristik yang sama. Yesus menjadi subjek bagi 20,2\% kata kerja (Burridge, 2004, p. 216). Berdasarkan hal ini Injil memiliki kesamaan dengan biografi kuno dalam cara menampilkan tokoh-tokoh dalam naratifnya, yaitu adanya satu tokoh yang menjadi sorotan dan berperan penting.

Ketiga, kesamaan lain yang terdapat antara Injil kanonik dan biografi kuno terletak pada fungsinya. Dengan unsur retorika yang dimiliki, kedua literatur digunakan sebagai instrumen persuasif untuk meyakinkan pembacanya untuk menerima atau menolak ideologi tertentu. Natur retorika ini selaras dengan konteks masyarakat Helenis: retorika memainkan peran penting. Retorika menjadi bagian dalam sistem pendidikan pada masa itu (Stamps, 2008, p. 506). Tentu tidak bisa dijelaskan secara detail sampai sejauh mana retorika secara formal mempengaruhi tulisan biografi. Namun, sebagaimana dijelaskan oleh Aune (1987, p. 31) bahwa menampilkan sesosok tokoh sebagai representasi adalah salah satu bentuk praktik beretorika di zaman kuno. Di samping itu, cara tulisan biografi kuno digunakan mengindikasikan natur retorikanya. Aune (1987, p. 35) mengatakan bahwa tulisan biografi kuno adalah alat propaganda yang efektif.

Terkait dengan fungsi retorikal biografi Yunani-Romawi, penting untuk membahas tentang bentuk retorika chreia, khusus dalam konteks kaitan antara biografi kuno dan Injil kanonik. Chreia merujuk kepada perkataan dan tindakan tokoh tertentu yang diungkapkan atau dituliskan kembali karena dianggap bermakna (lih. Hock \& O'Neil, 1986, p. 26; Watson \& Hauser, 1994, p. 177). Sebagaimana ditunjukkan oleh Watson dan Hauser (1994, p. 117): "The chreia is the basis of many rhetorical exercise described in progymnasmata (preliminary exercise), the rhetorical textbook written from the $1^{\text {st }}$ to the $5^{\text {th }}$ centuries A.D." Dalam biografi kuno, chreia adalah salah satu alat retorika yang digunakan (lih. Stamps, 2008, p. 508; Watson, 1992, pp. 104-106).

Di atas dijelaskan bahwa biografi kuno memiliki komponen retorika yang mendukung tujuan persuasif dari tulisan tersebut. Injil-Injil kanonik juga memiliki fungsi persuasif sebagaimana halnya dengan biografi kuno. Secara retoris, penulis kitab Injil mencoba untuk meyakinkan pembacanya tentang perspektif teologis terkait dengan identitas Yesus. Oleh sebab itu Aune (1987, p. 59) menyebut bahwa Kitab Injil bisa dikatakan sebagai "propagandistic Christian writings". Dalam Injil sinoptik, tujuan persuasif terekspresi secara implisit. Namun dalam Injil Yohanes, tujuan tersebut terlihat secara eksplisit:

Memang masih banyak tanda lain yang dibuat Yesus di depan mata murid-murid-Nya, yang tidak tercatat dalam kitab ini, tetapi semua yang 
tercantum di sini telah dicatat, supaya kamu percaya, bahwa Yesuslah Mesias, Anak Allah, dan supaya kamu oleh imanmu memperoleh hidup dalam nama-Nya (Yoh. 20:30-31).

Maka bisa dilihat bahwa Injil kanonik memiliki unsur retorik yang bertujuan persuasif.

Sebelumnya sudah dijelaskan tentang penggunaan format retorik chreia dalam biografi YunaniRomawi. Vernon K. Robbins dan D. F. Watson juga mengaitkan chreia dengan Kitab Injil sebagai salah satu gaya retorik yang terdapat dalam Injil kanonik (Robbins, 1988; lihat juga Stamps, 2008; Watson, 1992). Maka, dari segi fungsi, bisa dipahami bahwa Injil kanonik dan biografi Yunani-Romawi memiliki kesamaan. Keduanya digunakan secara persuasif untuk meyakinkan pembaca agar menerima atau menolak ide-ide tertentu. Untuk Injil tentu fungsi retorik tersebut bertujuan membawa pembaca menerima konsep Kristologis dan nilai-nilai yang termuat di dalamnya, yang dipresentasikan penulis melalui tokoh Yesus Kristus.

Dari uraian kesamaan antara biografi kuno dan Injil kanonik, maka ada dasar untuk mengategorikan kitab-kitab Injil sebagai tulisan biografi Yunani-Romawi. Dengan pemahaman genre seperti ini, maka ini akan menentukan bagaimana Injil-Injil kanonik harus diperlakukan, yaitu selaras dengan penggunaan tulisan-tulisan biografi dalam konteks Helenistik.

\section{Kelebihan Membaca Injil Kanonik Sebagai Biografi Kuno}

Terkait dengan keuntungan membaca InjilInjil kanonik sebagai tulisan biografi kuno. Makalah ini mencoba melihat hal ini dalam dua aspek, pertama, fakta bahwa teks diperlakukan sesuai dengan sistem historiografi di abad pertama. Ada perbedaan mendasar cara manusia modern menggunakan informasi historis bila dibandingkan pada masa YunaniRomawi. Bagi sejarawan kuno, cerita adalah alat retorika. Tulisan mereka bertujuan propaganda.

Di atas telah diulas bahwa unsur retorik dari teks sangat penting dalam konteks biografi kuno. Tidak seperti biografi modern yang cenderung menya- jikan informasi saja, biografi Yunani-Romawi mengajak pembaca untuk menerima konsep tertentu yang disajikan melalui narasi yang ada. Sehingga bukan detail informasi yang menjadi tujuan, melainkan ajakan terhadap pembaca.

Ketika Injil kanonik dibaca dengan pendekatan demikian, maka penafsir akan menggali gagasan-gagasan teologis yang penulis Injil inginkan untuk diterima oleh pembaca. Respons yang diharapkan penulis terhadap pembacanya adalah sasaran penggalian melalui pendekatan naratif biografi Yunani-Romawi.

Kedua, pembaca dapat fokus pada tokoh yang menjadi sorotan dalam teks. Tulisan biografi kuno tidak didesain menceritakan seluruh kejadian secara detail. Tokoh utama cerita merupakan pusat naratif yang merefleksikan gagasan yang akan disampaikan. Sebab itu, analisa yang berpusat pada tokoh utama, penting untuk mendalami Injil-Injil kanonik.

Injil-Injil kanonik menyajikan tentang Yesus Kristus. Dengan menyoroti laporan terkait dengan Yesus Kristus, penafsir telah melihat inti dari teks Injil. Dalam mendiskusikan dampak hermeneutis membaca Injil sebagai tulisan biografi kuno, Burridge memahami bahwa studi terhadap Injil harus menempatkan Yesus sebagai pusat bagi proses penafsiran (Burridge, 2004, pp. 248-250). Dengan memahami keberpusatan naratif pada Yesus, maka penafsir akan bisa sedekat mungkin dengan tujuan yang ingin dicapai oleh para penulis Injil.

Ketiga, membaca Injil sebagai tulisan yang bersifat persuasif akan menolong penafsir untuk melihat naratif Yesus Kristus sebagaimana fungsinya. Telah dijelaskan sebelumnya bahwa tulisan biografi kuno memiliki fungsi retoris. Dalam menekankan fungsi tersebut, Aune menjelaskan bahwa kitab-kitab Injil berfungsi meneguhkan keyakinan para pengikut Kristus, dengan secara persuasif menunjukkan identitas Yesus Kristus (Aune, 1987, pp. 59-60).

Secara umum naratif Alkitab mengajak pembaca untuk memberi respons. Ini dilakukan dengan menggunakan teknik retorika tertentu. Maka dengan menyadari adanya elemen-elemen retorik dalam 
teks, akan menolong pembaca memahami kisah dalam Injil-Injil kanonik secara lebih komprehensif. Resseguie menjelaskan bahwa, retorika sebagai unsur integral dari naratif adalah "alat yang digunakan oleh para penulis untuk meyakinkan kita tentang pandangan ideologi, norma, keyakinan dan nilai-nilai mereka" (Resseguie, 2015, p. 41). Dengan menggunakan alat retorika, penulis meletakkan dasar bagi ideologinya dan alasan mengapa itu signifikan bagi pembacanya. Dalam konteks tulisan Injil kanonik, jelas bahwa penulis menyajikan konsepsi berkaitan dengan Yesus Kristus. Maka dengan sistem retorika yang dibangunnya, penulis membuktikan bahwa konsepsi tersebut memiliki dasar yang kuat. Jadi dengan melihat sistem retorika, seorang penafsir tidak hanya menangkap makna cerita, melainkan juga dapat menjawab pertanyaan mengapa bisa demikian dan apa arti penting bagi kehidupan. Mendalami retorika tulisan menolong untuk melihat dimensi lain dari makna.

\section{Implikasi Hermeneutis}

Berdasarkan uraian di atas, kitab-kitab Injil memiliki kesamaan dengan tulisan biografi kuno. Kesamaan ini mengindikasikan bahwa kedua jenis tulisan berasal dari bentuk genre tulisan yang sama. Maka ada beberapa implikasi hermeneutis yang perlu untuk dipikirkan agar kitab Injil bisa didalami sebagaimana naturnya.

Pertama, penting terlebih dahulu meletakkan fondasi bahwa memahami genre tulisan InjilInjil kanonik tidak cukup berhenti pada bentuk tulisan naratif. Lebih jauh, penafsir harus memahami Injil sebagai bagian dari tulisan kuno. Sebagaimana dijelaskan sebelumnya, kritik naratif telah menjadi penyeimbang bagi metodologi yang berorientasi banyak pada pendekatan historis. Namun kritik naratif masih memperlakukan teks Alkitab sebagai naratif modern. Sistem literer kuno pada teks diabaikan.

Tapi bukan berarti pendekatan naratif tidak berguna sama sekali. Kritik naratif adalah langkah penting dalam analisa Injil-Injil kanonik. Pendekatan ini melihat natur cerita dari setiap Injil. Maka analisa terhadap unsur-unsur yang membangun naratif Injil baik bila diterapkan. Pendekatan biografi kuno akan menjadi tambahan berarti bagi pembacaan naratif Injil, karena teks akan dilihat sesuai naturnya sebagai tulisan bergenre biografi yang hadir dalam konteks dunia Yunani-Romawi di abad pertama.

Kedua, gagasan-gagasan teologis dalam kitab-kitab Injil berpusat pada Yesus Kristus. Pada prinsipnya, Injil-Injil kanonik bercerita tentang Yesus. Secara umum mereka menampilkan kehidupan Yesus dari kelahiran sampai dengan kematian dan kebangkitan-Nya. Sesuai dengan naturnya sebagai tulisan biografi Yunani-Romawi, maka keberadaan Yesus sebagai tokoh utama harus menjadi perhatian. Tokoh utama adalah media bagi penulis biografi untuk menyampaikan ideologinya.

Pada prinsipnya, dari sudut pandang biografi kuno, menelusuri secara mendalam perkataan dan perbuatan tokoh utama adalah penting, karena dari situlah didapat gagasan teologis yang ingin disampaikan penulis Injil (Licona, 2017, p. 4). Maka dalam membaca Injil-Injil kanonik, Yesus adalah kunci. Tentu tidak salah mendalami tokoh-tokoh lain, selain Yesus. Namun perlu diingat bahwa Yesus Kristus adalah sumber bagi gagasan teologis dalam kitab Injil.

Sebagai contoh, ketika membaca naratif Zakheus dalam Lukas 19:1-10, pembaca harus bisa membedakan Yesus sebagai tokoh utama dan Zakheus sebagai karakter pelengkap. Gagasan teologis dari perikop tersebut seharusnya terletak pada elemen cerita yang berkaitan dengan tokoh utama. Maka dalam hal ini, pernyataan Yesus dalam ayat 9, 10 menjadi kunci dan sumber gagasan teologis yang ingin disampaikan melalui perikop tersebut. Dalam kedua ayat tersebut dituliskan sebagai berikut:

Kata Yesus kepadanya [Zakheus]: "Hari ini telah terjadi keselamatan kepada rumah ini, karena orang ini pun anak Abraham. Sebab Anak Manusia datang untuk mencari dan menyelamatkan yang hilang."

Berdasarkan pernyataan ini, sangat mungkin penulis bertujuan menegaskan karya Sang Mesias dan dampaknya yang bersifat universal: Dia datang untuk semua orang, termasuk mereka yang terpinggirkan (lih. 
Glanville, 2009; Rodriguez, 2012; Byrne, 2015). Ini selaras dengan kerangka teologis keseluruhan Injil Lukas. Injil Lukas menegaskan bahwa kedatangan Yesus adalah untuk semua orang, termasuk kaum marginal. Di awal tulisannya, Lukas menempatkan fondasi teologis karya Yesus dalam Lukas 1:53, bahwa Allah melimpahkan kebaikan kepada mereka yang miskin (lapar). Sebagai Sang Utusan, Yesus memiliki tugas yang selaras dengan karakter Allah tersebut, sesuai dengan pernyataan dalam Lukas 4:18, 19 bahwa Dia diutus untuk orang-orang miskin, tawanan, buta dan tertindas. Kelompok orang yang termarginalkan ini muncul beberapa kali dalam Injil Lukas dengan beberapa variasi $(6: 20 ; 7: 22 ; 14: 13$; 14:21; 16:20, 22). Dengan demikian, Kristologi Injil Lukas menegaskan tentang datangnya Sang Mesias yang peduli terhadap mereka yang terpinggirkan. Berkaitan dengan konteks sosial orang-orang Yahudi di tanah Palestina, Zakheus yang adalah pemungut cukai termasuk di dalamnya-pemungut cukai dianggap sebagai orang berdosa karena telah menjadi kaki tangan Romawi, di samping banyak yang bertindak curang menekan masyarakat. Jadi kisah Zakheus, dalam kaca mata biografi Yunani-Romawi, sebaiknya dibaca dalam terang identitas tokoh utama, yaitu Yesus Kristus.

Ketiga, Injil harus dilihat lebih dari sekadar laporan, melainkan tulisan yang memiliki unsur retorika yang bertujuan untuk meyakinkan pembaca terhadap pandangan teologis tertentu. Sebelumnya telah dibahas bahwa tulisan biografi Yunani-Romawi bersifat persuasif. Tulisan tersebut bahkan bisa menjadi alat propaganda. Maka teks Injil memiliki unsur persuasif.

Keberadaan elemen retoris dalam tulisan naratif-historis Injil merupakan hal yang lumrah dalam konteks literatur dunia Yunani-Romawi. Dengan sejarawan yang pada umumnya mendapatkan pendidikan beretorika, maka historiografi Yunani-Romawi sangat dipengaruhi oleh retorika. Karakter yang menjadi tokoh utama dalam naratif dijadikan sebagai alat retorika oleh para sejarawan Helenistik untuk mempengaruhi pembaca mereka (Aune, 1987, p. 83). Tentu fungsi yang sama berlaku bagi InjilInjil kanonik. Sebelumnya telah dijelaskan unsur-unsur yang terdapat dalam kitab-kitab Injil yang mengindikasikan dimensi retorika Injil.

Hal yang perlu ditekankan adalah keberadaan tokoh utama Yesus bukanlah sekadar pelaporan, melainkan media untuk meyakinkan pembaca terhadap nilai hidup dan pelayanan Kristen. Sebagai contoh, dalam Lukas 4:18, 19 dituliskan:

Roh Tuhan ada pada-Ku, oleh sebab Ia telah mengurapi Aku, untuk menyampaikan kabar baik kepada orang-orang miskin; dan Ia telah mengutus Aku untuk memberitakan pembebasan kepada orang-orang tawanan, dan penglihatan bagi orang-orang buta, untuk membebaskan orang-orang yang tertindas, untuk memberitakan tahun rahmat Tuhan telah datang.

Tentu pernyataan di atas menjelaskan siapa Yesus dan karakter pelayanan-Nya. Namun dari sudut pandang biografi Yunani-Romawi, gagasan yang ada pada pernyataan tersebut tidak berhenti pada laporan tentang keberadaan Yesus, tetapi juga memiliki unsur retoris yang bertujuan meyakinkan pembaca tentang ideologi tertentu. Dan ini dapat dibawa kepada prinsip pelayanan Kristen. Jadi Yesus dalam naratif Injil tidak hanya dilaporkan, tetapi juga dijadikan sebagai landasan bagi nilai-nilai hidup dan pelayanan Kristiani. Maka pernyataan dalam Lukas 4:18, 19 bisa dijadikan sebagai dasar untuk mengajak gereja membangun sebuah pelayanan yang bersifat holistik. Berdasarkan karya dan perkataan Yesus dalam Injil Lukas, pelayanan Kristen harus menyentuh seluruh dimensi kehidupan warga gereja, termasuk kebutuhan sosial mereka.

\section{KESIMPULAN}

Dari uraian di atas jelas bahwa Injil-Injil kanonik, berkaitan dengan genrenya, sebaiknya dibaca sebagai tulisan biografi kuno. Ada kesamaankesamaan yang jelas terlihat antara teks-teks Injil dengan tulisan biografi Yunani-Romawi. Ketika memperlakukan Injil-Injil sesuai dengan naturnya yang adalah tulisan kuno, maka ada implikasi-implikasi hermenautis yang patut untuk diperhatikan. 
Mengingat pentingnya mendalami teks-teks Injil sesuai dengan naturnya, maka dibutuhkan studistudi yang lebih komprehensif terkait dengan penggunaan biografi Yunani-Romawi dalam konteks dunia Helenis di masa penulisan kitab-kitab Injil. Tujuannya adalah agar teks-teks Injil kanonik dapat dibaca sesuai dengan fungsinya. Dengan menggunakan pendekatan naratif-biografi, kisah kehidupan

\section{DAFTAR RUJUKAN}

Abogunrin, S. O. 2003. "Jesus' Sevenfold Programmatic Declaration at Nazareth: An exegesis of Luke 4.15-30 From an African Perspective." Black Theology, 1(2), 225-249.

Aune, D.E. 1987. The New Testament in Its Literary Environment. Philadelphia: Westminster Press.

Aune, D. E. 2003. The Westminster Dictionary of New Testament and Early Christian Literature and Rhetoric (1st ed.). Louisville, Ky: Westminster John Knox Press.

Banks, R. J. 1992. "Narrative Exegesis." In J. B. Green, S. McKnight, \& I. H. Marshall (Eds.), Dictionary of Jesus and the Gospels (pp. 570-571). Downers Grove, Ill: InterVarsity.

Bartchy, S. S. 1998. "Narrative Criticism." In P. H. Davids \& R. P. Martin (Eds.), Dictionary of the Later New Testament and Its Development (pp. 787-792). Downers Grove, IL: InterVarsity.

Burridge, R. A. 2004. What are the Gospels?: A Comparison with Graeco-Roman Biography (2nd ed). Grand Rapids, Mich.: Eerdmans.

Burridge, R. A. 2005. "Who Writes, Why, and for Whom?" In M. Bockmuehl \& D. A. Hagner (Eds.), Written Gospel (pp. 99-115). Cambridge; New York: Cambridge University Press.

Burridge, R. A. 2013. "Biography as the Gospels' Literary Genre." Revista Catalana de Teologia, 38 (1), 9-30.

Byrne, B. 2015. The Hospitality of God: A Reading of Luke's Gospel. Collegeville: Liturgical Press. dan pelayanan Yesus yang dilaporkan oleh penulis Injil akan memiliki makna bagi warga jemaat, karena tidak hanya sekedar dilihat sebagai laporan, karena salah satu kunci utama dalam literatur biografi Yunani-Romawi adalah tokoh utama yang ditampilkan adalah alat retorika untuk mengegaskan nilai atau ideologi tertentu.

Culpepper, R. A. 1983. Anatomy of the Fourth Gospel: A Study in Literary Design. Philadelphia: Fortress.

Finkel, A. 1994. "Jesus' Preaching in the Synagogue on the Sabbath (Luke 4. 16-28)." In C. A. Evans \& W. R. Stegner (Eds.), The Gospels and the Scriptures of Israel (pp. 325-341). Sheffield: Sheffield Academic Press.

Glanville, E. 2009. "Missiological Reflections on Difference: Foundations in the Gospel of Luke." Mission Studies, 26 (1), 64-79.

Green, J. B. 1972. The Gospel of Luke. Grand Rapids: Eerdmans.

Hill, D. 1971. Rejection of Jesus at Nazareth (Luke 4:16-30). Novum Testamentum, 13 (3), 161180.

Hock, R. F., \& O'Neil, E. N. 1986. The Chreia in Ancient Rhetoric: The Progymnasmata. Atlanta, Ga: Scholars.

Hurtado, L. W. 1992. "Gospel (Genre).” In J. B. Green, S. McKnight, \& I. H. Marshall (Eds.), Dictionary of Jesus and the Gospels. Downers Grove, Ill: InterVarsity Press.

Kimball, C. A. 1994. Jesus' Exposition of the Old Testament in Luke's Gospel. Sheffield: JSOT.

Kingsbury, J. D. 1988. Matthew as story (2nd ed.). Philadelphia: Fortress Press.

Kloppenborg, J. S. 2011. Gospels. In M. Coogan (Ed.), The Oxford Encyclopedia of the Books of the Bible (Vol. 1, pp. 334-349). Oxford: Oxford University Press. 
Licona, M. R. 2017. Why Are There Differences In The Gospels? What We Can Learn From Ancient Biography. New York: Oxford University Press.

Marshall, I. H. 1970. Luke: Historian and Theologian. Grand Rapids: Zondervan.

McKnight, E. V. 1992. Literary Criticism. In J. B. Green, S. McKnight, \& I. H. Marshall (Eds.), Dictionary of Jesus and the Gospels (pp. 473-481). Downers Grove, Ill: InterVarsity.

Ommeren, N. M. van. 1991. "Was Luke an Accurate Historian." Bibliotheca Sacra, 148 (589): 57-71.

Poirier, J. C. 2009. Jesus as an Elijianic Figure in Luke 4:16-30. Catholic Biblical Quarterly, 71 (2): 349-363.

Prior, Michael. 1995. Jesus the Liberator: Nazareth Liberation Theology (Luke 4. 16-30). Sheffield: Sheffield Academic Press.

Resseguie, J. L. 2015. Narrative Criticism of the New Testament: An Introduction. Grand Rapids: Baker Academic.

Rhoads, D. M., \& Michie, D. 1982. Mark as Story: An Introduction to the Narrative of a Gospel. Philadelphia: Fortress.

Ringe, S. H. 1981. "Luke 4:16-44: A portrait of Jesus as Herald of God's Jubilee." Proceedings, 1, 73-84.

Robbins, V. K. 1988. The Chreia. In D. E. Aune (Ed.), Greco-Roman Literature and the New Testament: Selected Forms and Genre (pp. 1-23). Atlanta, Ga: Scholars.

Rodriguez, D. L. 2012. The Liberating Mission of Jesus: The Message of the Gospel of Luke. Eugene: Wipf and Stock Publishers.
Siker, J. S. 1992. "First to the Gentiles": A Literary Analysis of Luke 4:16-30. Journal of Biblical Literature, 111 (1), 73-90.

Stamps, D. 2008. Rhetoric. In C. A. Evans (Ed.), Encyclopedia of the Historical Jesus (pp. 506509). New York: Routledge.

Talbert, C. H. 1988. "Once Again: Gospel Genre." Semeia, (43), 53-73.

Tannehill, R. C. 1986. The Narrative Unity of LukeActs: A Literary Interpretation (Vol. 1). Philadelphia: Fortress.

Tarmedi, P. A. D. 2013. "Analisis Naratif: Sebuah Metode Kristiani Hermeneutika Kitab Suci." Melintas, 29 (3).

Travis, S. H. 1977. Form Criticism. In I. H. Marshall (Ed.), New Testament interpretation: Essays on Principles and Methods (pp. 153-164). Carlisle: The Paternoster.

Uytanlet, S. 2014. Luke-Acts and Jewish Historiography: a Study on the Theology, Literature, and Ideology of Luke-Acts. Tübingen, Germany: Mohr Siebeck.

Walton, S. 2015. "What are the Gospels: Richard Burridge's Impact on Scholarly Understandding of the Genre of the Gospels." Currents in Biblical Research, 14 (1): 81-93.

Watson, D. F. 1992. Chreia/Aphorism. In J. B. Green \& S. McKnight (Eds.), Dictionary of Jesus and the Gospels (pp. 104-106). Downers Grove, IL; Leicester: InterVarsity.

Watson, D. F., \& Hauser, A. J. 1994. Rhetorical Criticism of the Bible: A Comprehensive Bibliography with Notes on History and Method. Leiden; New York: E.J. Brill. 